\title{
MENINGKATKAN PROFESIONALISME GURU MEMBUAT RENCANA PELAKSANAAN PEMBELAJARAN (RPP) MELALUI SUPERVISI BIMBINGAN PRIBADI DI SDN 91/IX RENGAS BANDUNG
}

\author{
Muhammad Basri \\ muhamadbasri099@gmail.com \\ SD Negeri 91/IX Rengas Bandung
}

\begin{abstract}
The urgency of research is there are still many teachers who find it difficult to develop, establish, to adjust, and then set up to make the Learning Implementation Plan, the right one and according to the characteristics of teaching materials, the nature of teaching materials and student development in general. The purpose of this study is to improve the professionalism of teachers to make lesson plans through supervision of personal guidance. This type of research is the School Action Research which consists of four main stages namely planning, action, observation, the research subjects consisted of 11 teachers from SDN 91 / IX Rengas Bandung, which consisted eight civil governent of teachers and three governent of teacher contract. The success criteria is a percentage of $85 \%$ in general and individually. The results showed that the total score of 39.09 in the first cycle increased significantly to 44.55 in the second cycle, the percentage of success of teachers $78.18 \%$ in the first cycle increased to $89.09 \%$ in the second cycle. The results obtained in the second cycle means that the achievement of teacher professionalism makes the implementation plan of learning by $85 \%$ in general or individually, therefore, it can be concluded that the supervision of personal guidance can improve the professionalism of teachers to make a Learning Implementation Plan at SDN 91 / IX Rengas Bandung.
\end{abstract}

Keywords: teacher professionalism, RPP, supervision of personal guidance

\section{ABSTRAK}

Urgensi penelitian yaitu masih banyak ditemukan guru yang kesulitan mengembangkan, memantapkan, menyesuaikan, menetapkan untuk kemudian membuat Rencana Pelaksanaan Pembelajaran (RPP) yang tepat dan sesuai dengan karakteristik bahan ajar, sifat bahan ajar dan perkembangan peserta didik. Tujuan penelitian ini yaitu meningkatkan profesionalisme guru membuat RPP melalui supervisi bimbingan pribadi. Jenis penelitian yaitu Penelitian Tindakan Sekolah (PTS) yang terdiri dari empat tahapan utama yaitu perencanaan, tindakan, pengamatan, lokasi penelitian yaitu SDN 91/IX Rengas Bandung Kabupaten Muaro Jambi. Waktu penelitian yaitu semester II tahun Ajaran 2017/2018. Subjek penelitian beranggotakan seluruh majelis guru SDN 19/IX Rengas Bandung yang berjumlah 11 orang guru yaitu delapan orang guru PNS dan tiga orang guru Non-PNS. Kriteria keberhasilan yaitu persentase sebesar $85 \%$ secara umum dan individual. Hasil penelitian menunjukkan bahwa skor sotal 39,09 pada siklus I meningkat dengan signifikan menjadi sebesar 44,55 pada siklus II, presentase keberhasilan guru 78,18\% pada siklus I meningkat menjadi sebesar $89,09 \%$ pada siklus II, hasil yang dicapai guru pada siklus II mengandung arti bahwa tercapainya profesionalisme guru membuat RPP sebesar $85 \%$ secara umum ataupun individual. Berdasarkan hasil dan temuan penelitian dapat disimpulkan bahwa supervisi bimbingan pribadi dapat meningkatkan profesionalisme guru membuat RPP di SDN 91/IX Rengas Bandung.

Kata Kunci: profesionalisme guru, RPP, supervisi bimbingan pribadi

\begin{tabular}{|c|c|c|}
\hline Submitted & Accepted & Published \\
\hline 2 September & 16 September 2019 & 19 September 2019 \\
\hline
\end{tabular}

\begin{tabular}{|l|c|c|c|}
\hline Citation & $:$ & $\begin{array}{r}\text { Basri, M. (2019). Meningkatkan Profesionalisme Guru Membuat Rencana Pelaksanaan Pembelajaran (RPP) Melalui } \\
\text { Supervisi Bimbingan Pribadi di SDN 91/IX Rengas Bandung. Jurnal PAJAR (Pendidikan dan Pengajaran), } \\
\text { 3(5), 1003-1014. DOI : http://dx.doi.org/ 10.33578/pjr.v3i5.7903. }\end{array}$ \\
\hline
\end{tabular}

*Copyright (C) 2019 Jurnal PAJAR (Pendidikan dan Pengajaran)

Publish by PGSD FKIP Universitas Riau, Pekanbaru, Indonesia

\section{PENDAHULUAN}

Guru yang memprofesional merupakan suatu keutuhan bagi terselenggaranya pendidikan yang baik, berkualitas, berdaya guna dan memiliki eksistensi yang kuat, dalam setting pendidikan formal di sekolah guru sebagai tenaga pendidik yang selanjutnya disebut sebagai petron penggerak dalam kancah Tut Wurihandayani menjadi pilar bagi pertumbuhan dan perkembangan kualitas regenerasi, baik kualitas kepribadian, sosial, keluarga dan kemasyarakatan sehingga kelak diharapkan memberikan warna 
tersendiri bagi Negeri Kesatuan Republik Indonesia (NKRI).

Guru yang profesional dalam menjalani proses belajar mengajar di kelas seyogianya memiliki standarisasi program pembelajaran sehingga memungkinkan proses dan hasil belajar dapat terukur, terarah, terkendali dan terpantau atas progres kualitas pembelajaran yang diberikan, manakala keseluruhan aspek kompetensi guru senantiasa terus dibina dan dikembangkan baik kompetensi pedagogik, pribadi, profesional dan sosial, diyakini memberikan nilai tambah bagi retorika proses pembelajaran dan kualitas serta mutu pendidikan di sekolah secara keseluruhan untuk mencapai tujuan tersebut persiapan guru dalam menjalani tugas sebagai pendidik yang profesional merupakan suatu keniscayaan.

Satu diantara persiapan guru dimaksud yaitu membuat Rencana Pelaksanaan Pembelajaran (RPP), dalam prosesnya seyogianya guru tidak hanya memiliki sebuah perangkat pembelajaran RPP namun juga mempunyai kompetensi dalam mengembangkan, memantapkan, menyesuaikan, dan menetapkan RPP. Pemilihan dan pengembangan di maksud yakni kesesuaian RPP dengan karakteristik bahan ajar, sifat bahan ajar dan perkembangan peserta didik. Sejalan dengan itu Sardiman, (2014: 135136) menyatakan secara garis besar ada tiga tingkatan kualifikasi profesional guru sebagai tenaga profesional kependidikan yaitu pertama tingkatan capability personal, kedua tingkatan guru sebagai inovator dan tingkatan ketiga guru sebagai developer. bertolak dari pernyataan tersebut mengindikasikan bahwa guru yang profesional hendaknya memiliki pengetahuan, kecakapan dan keterampilan serta sikap yang mantap serta memadai sehingga mampu mengolah proses belajar mengajar dengan baik dan efektif, memiliki kamampuan melihat berbagai tantangan yang dihadapi dan mampu melakukan dan memberikan respon yang tepat terhadap pembaharuan khususnya sektor pendidikan sebagai sebuah sistem.

Sejalan dengan itu sebuah penelitian kualitatif telah membuktikan pentingnya kemampuan guru dalam melaksanakan perannya sebagai pendidik di sekolah diantaranya: Paolini,
A (2015: 20-33) hasil penelitian menunjukkan bahwa guru yang melakukan pengajaran praktik berbasis bukti yang meliputi kesesuaian gaya pengajaran, metodologi yang tepat, bentuk penilaian yang sesuai, dan desain instruksi pembelajaran yang komprehensif memberikan nilai tambah terhadap hasil belajar peserta didik. Selanjutnya penelitian tindakan dalam pendidikan guru dilakukan oleh Hong, C,E. dan Lawrence, S,A (2011: 1-17) penelitian dengan fokus penyelidikan kelas, refleksi dan pengambilan kesimpulan berbasis data dengan desaint kajian pustakaan yaitu melakukan review terhadap penelitian tindakan kelas sebanyak 18 PTK dilanjutkan dengan melakukan refleksi terhadap guru tersebut dalam menjalani proses pembelajaran, hasil penelitian menemukan bahwa guru yang telah melakukan penelitian tindakan cenderung lebih professional dalam hal pengajaran, memahami bagaimana menemukan langkah-langkah secara lebih terperinci, menetepkan bagaimana merencanakan pembelajaran hingga melakukan evaluasi dan tindak lanjut.

Sekolah Dasar Negeri 91/IX Rengas Bandung Kecamatan Jambi Luar Kota Kabupaten Muaro Jambi Provinsi Jambi terhitung tahun ajaran 2017/2018 memiliki sembilan rombongan belajar (ROMBEL) dengan majelis guru sebanyak sembilan orang dan tiga orang tenaga kependidikan merupakan satu di antaran pendidikan formal yang menjalani proses belajar mengajar di kelas tidak luput juga dari perhatian peneliti yang sekaligus sebagai guru pada SD dimaksud yang diberikan tugas tambahan sebagai kepala sekolah, ikut berperan dalam melakukan proses perbaikan terutama kualitas proses dan hasil pembelajaran yang diyakini berimbas pada kualitas dan mutu pendidikan di sekolah secara keseluruhan.

Bedasarkan studi pendahuluan peneliti di tempat penelitian yang juga merupakan tempat dimana peneliti mengemban tugas sebagai kepala sekolah, bahwa tidak sedikit dan tidak jarang ditemukan guru yang masih kesulitan mengembangkan, memantapkan, menyesuaikan, menetapkan untuk kemudian membuat RPP yang tepat dan sesuai dengan karakteristik bahan ajar, sifat bahan ajar dan perkembangan peserta didik, 
pembelajaran cenderung berkesan memenuhi jam mengajar dan tuntutan profesi pendidik.

Hasil wawancara Bersama beberapa guru SD Negeri 91/IX Rengas Bandung yang selanjutnya menjadi subjek dalam penelitian ini mengakui masih lemahnya pemahaman untuk melakukan memantapkan, menyesuaikan, menetapkan untuk kemudian membuat RPP yang disesuaikan dengan karakteristik bahan ajar, sifat bahan ajar dan perkembangan peserta didik secara keseluruhan, guru cenderung pasif dan lebih memilih melengkapi bahan ajar sebagai tenaga pendidik dalam gejola tuntutan sertifikasi guru dengan kesan menafikkan profesionalisme kerja sebagai tenaga pendidik yang professional, akibatnya RPP yang disajikan terkesan yang penting ada. Melihat kondisi tersebut, sebagai pemimpin atau menajer sekolah peneliti merasa terpanggil dan menjadikan pemandangan tersebut sebagai tantangan tersendiri untuk disikapi dengan tepat dan bijak yang didasari atas pembenahan diri kearah mutu yang lebih baik sebagai manajer sekolah dan etos kerja profesionalisme guru dan mutu sekolah secara umum.

Dalam upaya menemukan langkah yang tepat, cepat dan berdaya guna sebagai respon kesenjangan yang ada, peneliti juga mempertimbangkan tugas sebagai kepala sekolah sekaligus membina standar kompetensi kepala sekolah yang diserahi tugas memimpin dan mengelola sekolah dalam upaya meningkatkan mutu pendidikan. Setelah menempuh kajian literatur, membaca temuan hasil penelitian yang relevan dan mutachir, terdapat begitu banyak alternatif solusi dalam mengatasi masalah profesionalisme guru yang minim terkait kemampuan membuat RPP yang tepat dan sesuai dengan bahan ajar, dan karakteristik peserta didik, dari beberapa alternatif solusi tersebut peneliti menemukan satu strategi yang dianggap tepat dan sesuai dengan eksistensi peneliti sebagai kepala sekolah, strategi dimaksud yaitu kegiatan supervisi yang dikembangkan menjadi supervisi bimbingan pribadi dengan memerhatikan kompleksitas beban kerja dan tugas masing-masing guru.

Beberapa hasil penelitian yang menujukkan keefektifan kegiatan supervisi dalam meningkatkan profesionalisme guru diantaranya: Rasmita,D (2019: 560) penelitian berjenis PTS yang dilakukan di SD Negeri 017 Pasir emas melibatkan subjek sebanyak delapan orang terdiri dari tiga guru laki-laki dan lima guru perempuan, tujuan penelitian yaitu meningkatkan kompetensi guru melaksanakan proses pembelajaran melalui kegiatan supervisi, hasi penelitian menunjukkan bahwa nilai rata-rata guru dalam proses pembelajaran siklus I sebesar 72.85 dengan kategori cukup. Setelah dilakukan siklus II, nilai kompetensi guru dalam proses pembelajaran mengalami peningkatan menjadi 88.00 dengan kategori sangat baik. Ini membuktikan bahwa, melalui supevisi akademik dapat meningkatkan kompetensi guru dalam pelaksanaan proses pembelajaran di SD Negeri 017 Pasir Emas.

Selanjutnya hasil yang sama juga dilakukan oleh Marjoni, (2019: 512) penelitian berjenis PTS menggunakan kegiatan supervisi dengan tujuan meningkatkan kemampuan guru menyusun penilaian proses $\mathrm{K} 13$, hasil penelitian menunjukkan bahwa kegiatan supervisi dapat meningkatkan kompetensi guru dalam menyusun penilaian proses pembelajaran dengan rata-rata proses pembelajaran pada siklus I sebesar $79 \%$ yang termasuk kategori cukup, selanjutnya meningkat pada siklus II menjadi 84,5\% dengan kategori baik. Penelitian menyimpulkan bahwa melalui kegiatan supervisi kemampuan guru dalam melakukan penilaian proses mengalami peningkatan dengan kategori baik. Selaras dengan hasil penelitian di atas selanjutnya penelitian exsperimen yang dilakukan oleh Kasa, Y (2016: 12-18) Penelitian menyimpulkan bahwa guru yang melakukan pendekatan, pemberian nasihat, bimbingan, arahan, reinforcement yang berbeda dan sesuai dengan kebutuhan peserta didik memberikan hasil belajar yang memuaskan.

Setelah menemukan probabilistik strategi yang dianggap tepat dalam hal ini supervisi bimbingan pribadi dalam meningkatkan profesionalisme guru membuat RPP selanjutnya melakukan kosolidasi bersama stakeholder yaitu pengawas pembina, beberapa kolega yang juga menjalani tugas sebagai kepala sekolah, dan guru senior yang dianggap cakap dan mumpuni untuk mendiskusikan kesenjangan dan penetapan langkah yang tepat akhirnya peneliti memiliki 
keyakinan yang kuat bahwa melalui kegiatan supervisi yang juga merupakan kompetensi yang harus dimiliki peneliti sebagai kepala sekolah merupakan jawaban yang tepat dalam upaya membenahi isu kesenjangan yang ada, selanjutnya agar hipotesis tersebut dapat terukur secara ilmiah maka peneliti tertarik mengangkat persoalan dimaksud dalam sebuah penelitian berjenis Penelitian Tindakan Sekolah (PTS) dengan tujuan meningkatkan profesionalisme guru membuat RPP.

Berangkat dari latar belakang sebagaimana di kemukakan di atas rumusan masalah dalam PTS ini yaitu bagaimana meningkatkan profesionalisme guru membuat Rencana Pelaksanaan Pembelajaran (RPP) melalui supervisi bimbingan pribadi di SDN 91/IX Rengas Bandung? Bertolak dari rumusan masalah

\section{KAJIAN TEORETIS}

\section{Rencana Pelaksanaan Pembelajaran (RPP)}

Menurut Susanto, A (2016: 22)

Perencanaan Pelaksanaan Pembelajaran (RPP) adalah rancangan pembelajaran mata pelajaran per-unit yang akan diterapkan guru dalam pembelajaran di kelas. Pada hakikatnya penyusunan RPP bertujuan merancang pengalaman belajar siswa untuk mencapai tujuan pembelajaran. Sejalan dengan itu Nasution (2013: 113) menyatakan alasan pentingnya membuat RPP yaitu dapat menolong guru untuk memikirkan pelajaran sebelum pelajaran itu diajarkan sehingga kesulitan belajar dapat diramalkan dan jalan keluarnya dapat dicari. Guru dapat mengorganisasi fasilitas, perlengkapan, alat bantu pengajaran, waktu dan isi dalam rangka untuk mencapai tujuan belajar seefektif mungkin serta menghubungkan tujuan dan prosedur kepada tujuan keseluruhan dari mata pelajaran yang diajarkan.

\section{Belajar dan Pembelajaran}

Selanjutnya kajian tentang belajar sebagaimana Sardiman, (2014: 89) menyatakan bahwa belajar adalah suatu proses untuk memperoleh motivasi dalam pengetahuan, keterampilan, kebiasaan dan tingkah laku. Berangkat dari pemahaman tersebut dapat dipahami bahwa belajar merupakan perubahan- tersebut yang menjadi tujuan dalam PTS ini yaitu: untuk mengetahui bagaimana meningkatkan profesionalisme guru membuat Rencana Pelaksanaan Pembelajaran (RPP) melalui supervisi bimbingan pribadi di SDN 91/IX Rengas Bandung. Manfaat penelitian yaitu bagi guru: menjadi professional dalam mengembangkan, memantapkan, menyesuaikan, menetapkan untuk kemudian membuat RPP secara mendiri yang sesuai dengan karakteristik bahan ajar, sifat bahan ajar dan perkembangan peserta didik secara keseluruhan, bagi peserta didik: menjadi outcame dari hasil persiapan guru yang professional sebelum akhirnya menjalani kegiatan proses pembelajaran, bagi sekolah: menjadi sumbangan dalam upaya pengembangan mutu sekolah dan mutu Pendidikan secara keseluruhan.

perubahan yang terjadi pada diri siswa, baik yang menyangkut aspek kognitif, afektif, dan psikomotor sebagai hasil dari kegiatan belajar. Sejalan dengan itu Susanto, (2016: 12) menyatakan beberapa faktor yang memengaruhi hasil belajar diantaranya faktor internal dan faktor eksternal. Faktor internal merupakan faktor yang bersumber dari dalam diri peserta didik, yang mempengaruhi faktor belajarnya. Sedangkan faktor eksternal yaitu faktor yang berasal dari luar diri peserta didik yang memengaruhi hasil belajar seperti keluarga, sekolah dan masyarakat.

Selanjutnya mengingat proses pembelajaran di kelas dalam sebuah lingkungan belajar maka kinerja mengajar guru merupakan faktor penting lainnya hal tersebut sebagaimana Westra (Susanto, A, 2016: 28) mengemukakan bahwa kinerja guru yang selanjutnya disebut dengan performance dipandang sebagai suatu proses untuk mencapai tujuan dan hasil kerja, kinerja yang dilakukan dengan maksimal diyakini menghasilkan sesuatu yang baik dan maksimal. Sementara itu Daryanto, (2018: 32) mengemukakan bahwa guru adalah komponen yang sangat menentukan dalam implementasi suatu pembelajaran. 


\section{Supervisi Akademik}

Sedangkan kajian mengenai supervisi Sagala, S (2009: 121) menyatakan bahwa supervisi akademik merupakan bantuan dan bimbingan profesional bagi guru dalam melaksanakan tugas instruksional guna memperbaiki hal belajar dan mengajar dengan cara memberikan rangsangan, koordinasi, dan bimbingan secara terus menerus baik secara individual maupun kelompok. Sejalan denga itu Arikunto, (2006: 142) menyatakan tujuan umum supervisi akademik yaitu memberikan bantuan teknis dan bimbingan kepada guru (dan staf sekolah yang lain) agar personil tersebut mampu meningkatkan kualitas kinerjanya, terutama dalam melaksanakan tugas, yaitu melaksanakan proses pembelajaran. Lebih jauh lagi Soetjipto \& Kosasi, (2007: 86) menyatakan bahwa supervisi merupakan semua usaha yang dilakukan oleh supervisor untuk memberikan bantuan kepada guru dalam memperbaiki pengajaran. Berdasarkan beberapa pernyataan mengenai supervisi di atas dapat di simpulkan bahwa kegiatan supervisi merupakan serangkaian kegiatan yang dilakukan oleh supervisor secara professional dalam rangka membantu, membina, membimbing guru memperbaiki hal belajar mengajar yang dilakukan secara terus menerus baik secara individu maupun kelompok.

Dalam pencapaian kualitas proses dan hasil pembelajaran yang berimplikasi terhadap mutu sekolah secara keseluruhan maka, kompetensi kepala sekolah yang memadai dan mumpuni merupakan sesuatu yang sulit dipisahkan sebagaimana Djaali (2015: 17) menyatakan bahwa kepala sekolah adalah jabatan pemimpin yang tidak bisa diisi oleh orang-orang tanpa didasarkan atas pertimbanganpertimbangan. Sebagai pemimpin pendidikan, seorang kepala sekolah selain berfungsi sebagai administrator juga berfungsi sebagai supervisor yang intinya memberi layanan professional dalam meningkatkan kompetensi professional guru maupun kepala sekolah itu sendiri baik secara langsung maupun secara tidak langsung Hamdi (2018: 117). Lebih jauh Jakni (2017: 18) menyatakan bahwa kepala sekolah sebagai pemimpin di sekolah harus mampu mengelolah, memperhatikan, mengawasi dan membimbing para guru dalam proses belajar mengajar, salah satu caranya adalah dengan melakukan pengawasan terhadap guru yang sedang melaksanakan tugasnya di sekolah, hal tersebut diyakini memengaruhi peningkatan profesionalisme guru dalam melaksanakan proses belajar mengajar.

Berikutnya mengingat treatment yang digunakan dalam penelitian ini yaitu supervisi bimbingan pribadi yang disadur dan dikembangkan dalam perspektif layanan bimbingan dan konseling dengan memfokuskan dan menyesuaikan tatanan peneliti dalam melakukan supervisi akademik sebagai manajer sekolah, dalam prosesnya peneliti memberikan supervisi bimbingan pribadi kepada masingmasing guru SDN 91/IX Rengas Bandung dalam mengembangkan, memantapkan, menyesuaikan, menetapkan untuk kemudian membuat RPP yang tepat dan sesuai dengan karakteristik bahan ajar, sifat bahan ajar dan perkembangan peserta didik. Kaidah pelaksanaan supervisi bimbingan pribadi mempedomani unsur-unsur dan aspek-aspek RPP KTSP 2006 yang hingga sekarang masih digunakan sekolah, aspek dimaksud dalam RPP tersebut yaitu kesesuaianan indikator dengan Kompetensi dasar (KD); kesesuaian materi pokok dengan $\mathrm{KD}$; kesesuaian tujuan pembelajaran dengan $\mathrm{KD}$; metode pembelajaran yang tepat yang sesuai dengan karakteristik bahan ajar, sifat bahan ajar dan karakteristik perkembangan peserta didik secara keseluruhan; ketepatan langkah-langkah pembelajaran yang terdiri dari tiga unsur kegiatan yaitu kegiatan Awal, kegiatan Inti dan kegiatan penutup; hari efektif dan hari belajar efektif yang disesuaikan dengan kalender Pendidikan Nasional dan kalender Pendidikan sekolah; alokasi waktu yang disesuaikan dengan muatan pembelajaran dan standar kompetensi yang akan dicapai; bentuk penilaian yang tepat yang disesuaikan dengan sifat bahan ajar dan karakteristik pelajaran; Evaluasi dan tindak lanjut yang sesuai dengan sifat bahan ajar. Keseluruhan unsur dan aspek tersebut pula yang menjadi tolok ukur keberhasilan dalam penelitian ini yang dihimpun dalam bentuk penjaringan data pada lembar observasi dan pengamatan. 


\section{METODE PENELITIAN}

Jenis penelitian ini yaitu penelitian tindakan sekolah (PTS) dengan mempedomani ciri khas pelaksanaan penelitian tindakan (action research) model Kemmis \& Taggart yang terdiri dari empat kegiatan utama yaitu: (1) perencanaan, (2) tindakan, (3) pengamatan, dan (4) refleksi (Hamdi, M. 2018: 106). Adapun tahapan dimaksud dapat dilihat pada Gambar I berikut:

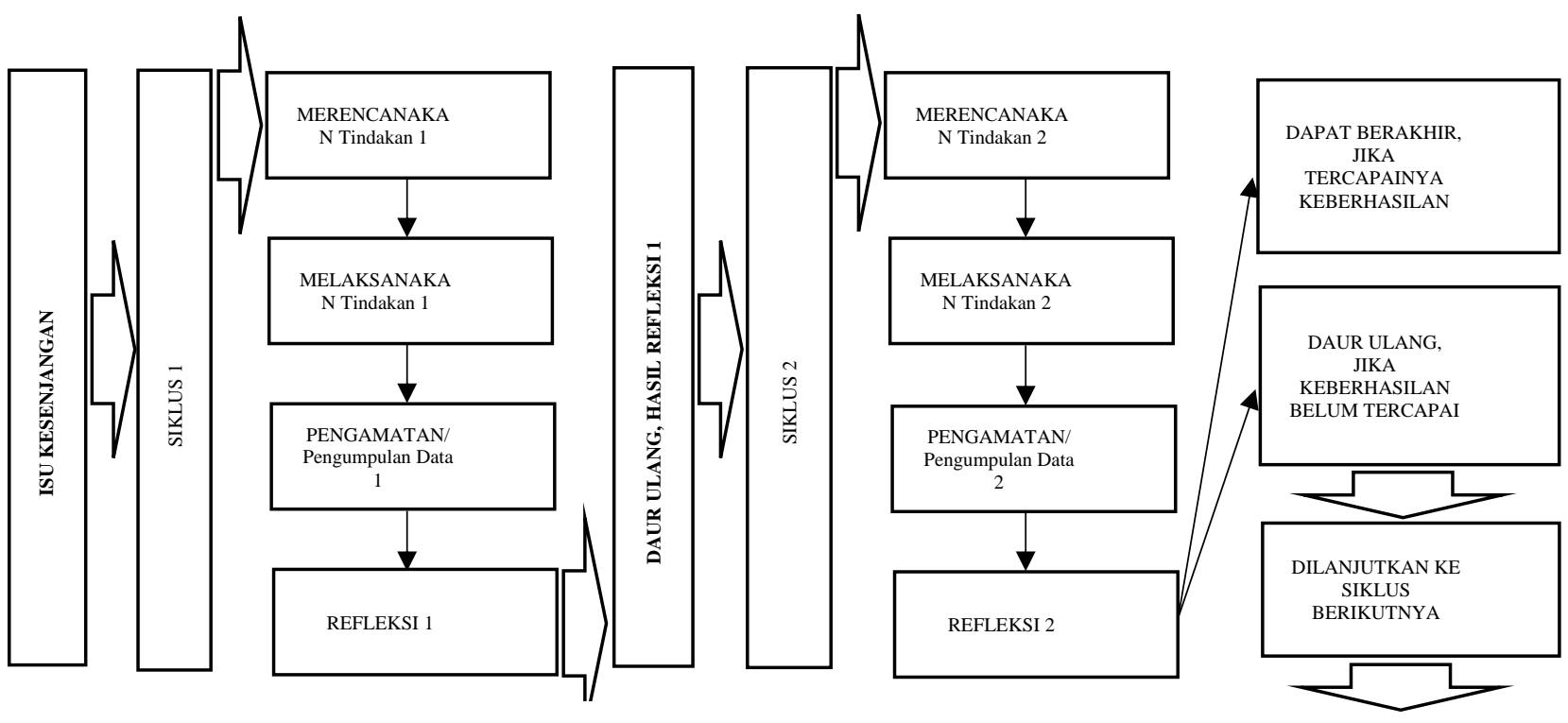

Gambar 1. Penelitian Tindakan

Berdasarkan Gambar 1 di atas dapat dipahami bahwa penelitian tindakan sekolah di awali dengan siklus pertama yang terdiri dari empat tahapan, manakala keberhasilan dan atau hambatan sudah diketahui pada tahap refleksi selanjutnya peneliti menentukan rancangan memasuki siklus 2 kegiatan terus berdaur ulang hingga siklus dapat dihentikan manakala tercapainya keberhasilan.

Adapun yang menjadi lokasi penelitian yaitu SDN 91/IX Rengas Bandung Kecamatan Jambi Luar Kota Kabupaten Muaro Jambi, waktu penelitian yaitu semester II tahun ajaran 2017/2018, subjek penelitian beranggotakan seluruh majelis guru SDN 19/IX Rengas Bandung yang berjumlah 11 guru terdiri dari delapan guru PNS dan tiga Guru Non PNS, Teknik pengumpulan data berupa pedoman observasi yang terdiri dari indikator keberhasilan guru membuat RPP, dalam prosesnya peneliti dibantu oleh tiga orang kolaborator penelitian yang selanjutnya bertindak sebagai observer yaitu satu orang pengawas Pembina, dan dua orang kepala sekolah tentangga yakni kepala sekolah SDN 18/IX Rengas bandung dan kepala sekolah SDN 104/IX Kedemangan, pemilihan dua kepala sekolah tersebut berangkat dari keyakinan kompetensi yang cakap dan mumpuni terkait fokus penyelesaian permasalahan yang di angkat dalam penelitian.

Indikator observasi dan pengamatan guru membuat RPP yang sesuai dengan karakteristik bahan ajar, sifat bahan ajar dan perkembangan peserta dapat dilihat pada Tabel 1. 
Tabel 1. Indikator Observasi Keberhasilan Guru Membuat RPP

\begin{tabular}{cl}
$\begin{array}{c}\text { No } \\
\text { Item }\end{array}$ & \multicolumn{1}{c}{ Indikator } \\
\hline 1 & Antusiasme Guru mengikuti supervisi bimbingan Pribadi \\
\hline 2 & Membuat indikator dalam RPP yang disesuaikan dengan KD \\
\hline 3 & Memilih apa yang menjadi materi pokok yang disesuaikan dengan KD \\
\hline 4 & Membuat tujuan pembelajaran yang disesuikan dengan idikator dan KD \\
\hline 5 & $\begin{array}{l}\text { Memilih metode pembelajaran yang tepat yang sesuai dengan karakteristik bahan ajar, sifat } \\
\text { bahan ajar dan perkembangan peserta didik secara keseluruhan }\end{array}$ \\
\hline 6 & $\begin{array}{l}\text { Membuat langkah-langkah pembelajaran yang terdiri dari tiga unsur kegiatan yaitu kegiatan } \\
\text { Awal, kegiatan Inti dan kegiatan penutup }\end{array}$ \\
\hline 7 & $\begin{array}{l}\text { Membuat hari efektif dan hari belajar efektif yang disesuaikan dengan kalender Pendidikan } \\
\text { Nasional dan kalender Pendidikan sekolah }\end{array}$ \\
\hline 8 & $\begin{array}{l}\text { Membuat alokasi waktu yang disesuaikan dengan muatan pembelajaran dan standar kompetensi } \\
\text { yang akan dicapai }\end{array}$ \\
\hline 9 & $\begin{array}{l}\text { Membuat bentuk-bentuk penilaian yang tepat yang disesuaikan dengan sifat bahan ajar dan } \\
\text { karakteristik pelajaran }\end{array}$ \\
\hline 10 & Evaluasi dan tindak lanjut sesuai dengan sifat bahan ajar \\
\hline
\end{tabular}

Selanjutnya teknik analisis data berupa data hasil observasi kolaborator selanjutnya ditabulasi dalam bentuk persentase senderhana dengan rumus:

Rumus yang digunakan untuk menjaring profesionalisme guru membuat RPP secara keseluruhan yaitu:

$x=\frac{N}{s t} x 100$

Keterangan:

$$
\begin{array}{ll}
x & : \text { Kompetensi } \\
N & \text { : Jumlah yang mencapai kompetensi } \\
\text { st } & \text { : Jumlah partisipan seluruhnya. }
\end{array}
$$

Hamdi, M (2018; 148)

Sedangkan rumus yang digunakan untuk menjaring profesionalisme guru membuat RPP secara individu yaitu

\section{HASIL DAN PEMBAHASAN}

Siklus I

Rencana Tindakan $p k=\frac{s p}{s m} x 100$

Keterangan:

$p k \quad$ : Persentase individu

$s p \quad$ : Skor yang diperoleh

sm : Skor maksimal.

Hamdi, M (2018: 122)

Selanjutnya kriteria keberhasilan yaitu penelitian dikatakan berhasil manakala pencapaian indikator keberhasilan profesionalisme guru membuat RPP sebesar $85 \%$ secara umum dan secara individual, penetapan kriteria keberhasilan dalam penelitian ini melibatkan kolaborator penelitian dengan memerhatikan poin-poin yang dianggap dapat dikembangkan secara mandiri oleh guru.

Pada tahapan ini kegiatan yang dilakukan peneliti diantaranya sebagai berikut: 
1. Menyusun program perencanaan tindakan dan jadwal supervisi bimbingan pribadi terhadap masing-masing guru dalam upaya meningkatkan profesionalisme guru membuat RPP dengan mempedomani standar isi mengingat sekolah masih menerapkan kurikulum KTSP;

2. Mensolidkan dan menyesuaikan waktu pelaksanaan dengan kegiatan sekolah yaitu dimulai dari bulan Maret 2017 s.d Mei 2018;

3. Mempersiapkan panduan yang akan digunakan dalam melakukan bimbingan pribadi terhadap guru membuat RPP;

4. Mensosialisasikan dan memastikan personil yang terlibat yaitu seluruh majelis guru SDN 91/IX rengas bandung dengan pendampingan pengawas pembina sekaligus mengharapkan berkenannya menjadi kolaborator penelitian;

5. Menyiapkan isntrumen pengukuran, pedoman observasi, dan daftar hadir;

6. Memastikan tegangan arus listrik dapat beroperasi dengan stabil;

7. Melakukan konsolidasi dengan dua kolaborator penelitian lainnya yang dianggap cakap berkompeten dan mumpuni yaitu kepala sekolah SDN 18/IX rengas bandung dan kepala sekolah 104/IX kedemangan;

8. Menyiapkan media yang dibutuhkan;

9. Memastikan kembali bahwa seluruh kebutuhan yang diperlukan untuk melakukan tindakan terpenuhi namun jika belum terpenuhi maka peneliti mencarikan alternatif solusi. Tahapan akan berlanjut ke tahap tindakan manakala semua kebutuhan sudah terpenuhi.

\section{Pelaksanaan Tindakan Siklus I}

Adapun kegiatan pada pelaksanaan tindakan siklus I merupakan lanjutan dari tahapan rencana tindakan, pada prosesnya peneliti melakukan tindakan nyata atau berhadapan langsung dengan subjek penelitian yang mempedomani skenario tindakan sebagaimana yang telah disusun sebelumnya yaitu supervisi bimbingan pribadi kepada guru dalam membuat RPP. Adapun pelaksanaan tindakan siklus I yang lebih terperinci dapat diuraikan sebagai berikut:

1. Dengan mempedomani standar isi KTSP guru dibimbing dapat memahami karakteristik bahan ajar, sifat bahan ajar dan perkembangan peserta didik secara keseluruhan di kelas masing-masing;

2. Guru dibimbing dapat memahami muatan secara detail RPP kurikulum KTSP;

3. Guru dibimbing dapat memahami Standar Kompetensi (SK) dan Kompetensi Dasar (KD) yang termuat pada kurikulum KTSP;

4. Memberikan kesempatan kepada guru untuk melakukan koreksi terhadap karakteristik bahan ajar, sifat bahan ajar dan perkembangan peserta didik secara keseluruhan;

5. Membimbing guru membuat indikator dalam RPP yang disesuaikan dengan KD;

6. Membimbing guru memilih apa yang menjadi materi pokok yang disesuaikan dengan KD;

7. Membimbing guru membuat tujuan pembelajaran yang disesuikan dengan idikator dan KD;

8. Membimbing guru memilih metode pembelajaran yang tepat yang sesuai dengan karakteristik bahan ajar, sifat bahan ajar dan perkembangan peserta didik secara keseluruhan;

9. Membimbing guru membuat pengalaman pembelajaran yang meliputi langkah-langkah pembelajaran yang terdiri dari tiga unsur kegiatan yaitu kegiatan Awal, kegiatan Inti dan kegiatan penutup;

10.Membimbing guru membuat hari efektif dan hari belajar efektif yang disesuaikan dengan kalender Pendidikan Nasional dan kalender Pendidikan sekolah;

11.Membimbing guru membuat alokasi waktu yang disesuaikan dengan muatan pembelajaran dan standar kompetensi yang akan dicapai;

12.Membimbing guru membuat bentuk-bentuk penilaian yang tepat yang disesuaikan dengan sifat bahan ajar dan karakteristik pelajaran;

13.Membimbing guru membuat kegiatan evaluasi dan tindak lanjut sesuai dengan sifat bahan ajar.

Kegiatan observasi dan pengamatan siklus I berlangsung bersaman dengan pelaksanaan tindakan, pada prosesnya peneliti di bantu tiga orang kolaborator penelitian yang bertindak sebagai observer dengan melakukan ceklis pada lembar pedoman observasi yang telah 
peneliti persiapkan sebelumnya, tiga orang observer dimaksud yaitu satu orang pengawas Pembina, kepala sekolah SDN 18/IX Rengas Bandung, dan kepala sekolah SDN 104/IX
Kedemangan. Adapun hasil observasi pengamatan keberhasilan siklus I dapat dilihat pada Tabel 2

Tabel 2. Observasi Keberhasilan Guru Siklus I

\begin{tabular}{cccccc}
\multirow{2}{*}{ Siklus } & \multicolumn{5}{c}{ Keberhasilan Guru } \\
\cline { 2 - 5 } & f & Total Skor & Skor Max & \% & Ketercapaian (85\%) \\
\hline I & 7 & 39,09 & 50,00 & 78,18 & Belum Tercapai \\
\hline
\end{tabular}

Berdasarkan observasi keberhasilan guru siklus I sebagaimana terlihat pada Tabel 2 di atas dapat dilihat bahwa skor total keberhasilan guru menunjukkan sebesar 39,09 dengan jumlah guru yang telah mencapai sebanyak tujuh orang guru, skor persentase keberhasilan menunjukkan sebesar 78,18\%, hasil tersebut mengindikasikan bahwa masih terdapat empat orang guru yang belum mencapai kriteria sebesar 85\% keberhasilan membuat RPP yang sesuai dengan karakteristik bahan ajar, sifat bahan ajar dan perkembangan peserta didik secara keseluruhan, dengan demikian penelitian berlanjut pada siklus II.

\section{Siklus II}

Kegiatan siklus II pada penelitian ini merupakan tahapan lanjutan atas temuan yang didapat pada tahap refleksi siklus I dengan melakukan perbaikan-perbaikan pada pin-poin yang dianggap perlu sehingga dapat kembali meningkatkan profesionalisme guru membuat RPP yang disesuaikan dengan karakteristik bahan ajar, sifat bahan ajar dan perkembangan peserta didik.

Setelah peneliti memasuki tahap rencana tindakan yang umumnya menempuh langkahlangkah yang cenderung sama pada siklus I dengan melakukan perbaikan pada aspek tertentu untuk diulang kembali pada siklus II hasil pelaksanaan tindakan siklus II dapat dilihat pada Tabel 3

Tabel 3. Observasi Keberhasilan Guru Membuat RPP Siklus II

\begin{tabular}{|c|c|c|c|c|c|}
\hline \multirow{2}{*}{ Siklus } & \multicolumn{4}{|c|}{ Keberhasilan Guru } & \multirow{2}{*}{$\begin{array}{c}\text { Ketercapaian } \\
(85 \%)\end{array}$} \\
\hline & $\mathbf{f}$ & Total Skor & Skor Max & $\%$ & \\
\hline I & 11 & 44,55 & 50,00 & 89,09 & Tercapai \\
\hline
\end{tabular}

Berdasarkan observasi keberhasilan guru siklus II sebagaimana terlihat pada Tabel 3 di atas dapat dilihat bahwa persentase yang dicapai guru pada siklus II yaitu sebesar $89,09 \%$ dengan kata lain secara umum guru telah mencapai kriteria keberhasilan $85 \%$ sebagaimana yang telah ditetapkan dalam penelitian ini sebagai tolok ukur keberhasilan guru membuat RPP yang sesuai dengan karakteristik bahan ajar, sifat bahan ajar dan perkembangan peserta didik, pencapaian tersebut mengindikasikan bahwa penelitian tindakan sekolah (PTS) dapat diakhiri pada siklus II.

\section{Pembahasan}


Berdasarkan observasi keberhasilan guru siklus I sebagaimana terlihat hasil yang diperoleh pada siklus I bahwa skor total keberhasilan guru menunjukkan sebesar 39,09 dengan jumlah guru yang telah mencapai sebanyak tujuh orang guru, skor persentase keberhasilan menunjukkan sebesar 78,18\%, hasil tersebut mengindikasikan bahwa masih terdapat empat orang guru yang belum mencapai kriteria sebesar $85 \%$ keberhasilan membuat RPP yang sesuai dengan karakteristik bahan ajar, sifat bahan ajar dan perkembangan peserta didik secara keseluruhan. Pada prosesnya peneliti dibantu kolaborator penelitian untuk menjaring data mengenai keberhasilan guru membuat RPP denga melakukan pengisian pada lembar observasi yang sebelumnya telah dilengkapi kriteria-kriteria keberhasilan guru membuat RPP denga mempedomani standarisasi RPP pada kurikulum KTSP yang hingga kini masih diterapkan sekolah SDN 91/IX Rengas Bandung.

Dari hasil refleksi siklus I yaitu melakukan pertemuan bersama kolaborator penelitian ditemukan bahwa secara umum guru masih terlihat ragu, pesimis, minder dan terlihat belum sepenuhnya menginginkan pembenahan pengetahuan terkait bagaimana menyusun RPP yang sesuai dengan karakteristik bahan ajar, sifat bahan ajar dan perkembangan peserta didik, hal tersebut di duga guru merasa kelelahan karena kegiatan supervisi dilakukan di akhir jam sekolah, disisi lain guru terlihat merasa terbebani karena perangkat pembelajaran yang lain belum sempurna diselesaikan dan agaknya tidak menginginkan diketahui oleh supervisor.

Berdasarkan hasil pelaksanaan tindakan siklus I dapat diketahui bahwa terjadinya peningkatan profesionalisme guru membuat RPP yang sesuai dengan karakteristik bahan ajar, sifat bahan ajar dan perkembangan peserta didik secara keseluruhan, data tersebut sebagaimana hasil tabulasi persentase keberhasilan guru yaitu sebesar 78,18\%. Namun demikian mengingat kriteria keberhasilan yang ditetapkan dalam PTS ini yaitu telah tercapainya $85 \%$ profesionalisme guru membuat RPP baik secara umum ataupun individual dengan demikian penelitian berlanjut pada siklus II.
Adapun rencana perbaikan yang didapat pada tahap refleksi siklus I untuk kemudian dilakukan kembali pada siklus II di diuraikan sebagai berikut

1. Supervisi bimbingan pribadi membuat indikator RPP perlu ditingkatkan dengan menyajikan banyak contoh lainnya;

2. Supervisi bimbingan pribadi membuat tujuan RPP perlu penguatan, dengan memvisualisasikan kepada guru dalam bentuk contoh kongkrit kegiatan keseharian peserta didik;

3. Supervisi bimbingan pribadi terkait metode pembelajaran yang tepat perlu diperbaiki, dengan membimbing guru mengkaji literatur keterhandalan metode yang disesuaikan dengan karakteristik bahan ajar, sifat bahan ajar dan perkembangan peserta didik;

4. Supervisi bimbingan pribadi membuat hari efektif dan hari belajar efektif yang disesuaikan dengan kalender Pendidikan Nasional dan kalender Pendidikan sekolah perlu diperkuat;

5. Supervisi bimbingan pribadi membuat bentukbentuk penilaian perlu penguatan contohcontoh;

6. Supervisi bimbingan pribadi membuat kegiatan evaluasi dan tindak lanjut perlu penguatan kembali dengan menyajikan contoh-contoh tambahan yang relevan;

Setelah peneliti menemukan hal-hal yang perlu dibenahi untuk kemudian dilakukan kembali pada tahap siklus II, akhirnya peneliti dapat melihat dengan lebih jelas beberapa kelemahan peneliti. Mengingat hasil pada siklus I menunjukkan masih terdapat empat orang guru yang belum mencapai kriteria keberhasilan membuat RPP sebesar $85 \%$ secara individu maka, penelitian berlanjut pada siklus II dengan menempuh tahapan sebagaimana yang ditempuh pada siklus I sebelumnya, yaitu perencanaan, tindakan, pengamatan, dan refleksi.

Setelah dilakukan tindakan pada siklus II dengan melakukan perbaikan pada poin-poin yang telah ditetapkan untuk dilakukan kembali pada siklu II baru kemudian hasil yang diperoleh guru dalam membuat RPP yang sesuai dengan karakteristik bahan ajar, sifat bahan ajar dan karakteristik peserta didik baik secara individu 
telah mencapai kriteria keberhasilan sebesar $85 \%$, dengan pencapaian tersebut penelitian dapat berakhir pada siklus II.

\begin{tabular}{cccccc}
\hline \multirow{2}{*}{ Siklus } & \multicolumn{4}{c}{ Skor Kompetensi Guru } & \multirow{2}{*}{$\begin{array}{c}\text { Ketercapaian } \\
\text { nyynnnn}\end{array}$} \\
\cline { 2 - 5 } & $\mathbf{f}$ & Total Skor & Skor Max & \% & Belum Tercapai \\
\hline I & 7 & 39,09 & 50 & 78,18 & Tercapai \\
\hline II & 11 & 44,55 & 50 & 89,09 & \\
\hline
\end{tabular}

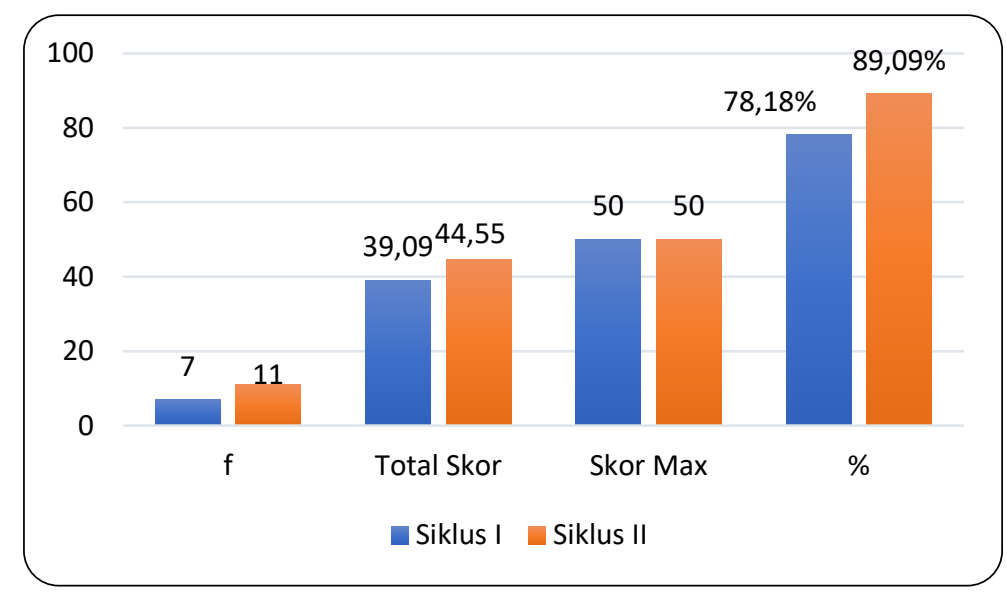

Gambar 2. Keberhasilan Guru Siklus I dan Siklus II

Berdasarkan rekapitulasi hasil observasi guru sebagaimana terlihat pada Tabel 4 di atas dapat dilihat bahwa total skor yang semula 39,09 pada siklus 1 meningkat menjadi sebesar 44,55 pada siklus II, hal yang sama juga terjadi pada

\section{SIMPULAN DAN REKOMENDASI}

Berdasarkan temuan hasil dan uraian pembahasan penelitian dapat ditarik kesimpulan bahwa: melalui supervisi bimbingan pribadi dapat meningkatkan profesionalisme guru membuat Rencana Pelaksanaan Pembelajaran (RPP) di SDN 91/IX Rengas Bandung.

Secara eksplisit temuan penelitian dapat disimpulkan sebagai berikut:

1. Profesionalisme guru membuat RPP melalui supervisi bimbingan pribadi di SDN 91/IX Rengas Bandungyang dijaring melalui pedoman observasi dan pengamatan meningkat dengan signifikan dari siklus ke
Adapun rekapitulasi hasil kompetensi guru pada siklus I dan siklus II dapat dilihat pada Tabel 4 
peneliti berikan yaitu

1. Bagi kepala sekolah: hasil temuan ini menjadi referensi dalam upaya meningkatkan profesionalisme guru membuat RPP yang sesuai dengan karakteristik bahan ajar, sifat bahan ajar dan perkembangan peserta didik;

2. Bagi guru membina professionalisme kerja sebagai Pendidik yang professional dengan membuat RPP yang sesuai dengan

\section{DAFTAR PUSTAKA}

Arikunto. (2006). Prosedur Penelitian Praktik (VI ed.). Jakarta: Rineka Cipta.

Daryanto. (2018). Penelitian Tindakan Kelas dan Penelitian Tindakan Sekolah Berserta Contoh-contohnya. Yogyakarta: GAVA MEDIA.

Djaali. (2015). Psikologi Pendidikan (9 ed.). Jakarta: Bumi Aksara.

Hamdi, M. (2018). Penelitian Tindakan Sekolah (PTS) Teori dan Praksis dalam Pendidikan. Jambi: UNJA Press.

Hong, C. P., \& Lawrence, S. A. (2011). Action Research in Teacher Education: Classroom Inquiry, Reflection, And Data-Driven Decision Making. Journal of Inquiry \& Action in Education, 4(2), 1 - 17.

Jakni. (2017). Penelitian Tindakan Kelas. Bandung: Alfabeta.

Kasa, Y. (2016, Juni). Improving Student's Participation in the Classroom in Chemistry Freshman Students at Assosa University: An Experimental Action Research. International Journal of Education, Culture and Society, 1(1), 12 - 18.

Marjoni. (2019, Mei). Upaya Meningkatkan Kompetensi Guru SDN 020 Langsat Hulu dalam Menyusun Penilaian Proses K13 Melalui Supervisi Akademik. Jurnal PAJAR (Pendidikan dan Pengajaran), 3(3), $512-520$.

Nasution. (2013). Berbagai Pendekatan dalam Proses Belajar \& Mengajar (16 ed.). Jakarta: PT Bumi Aksara.

Paolini, A. (2015). Enhancing Teaching Effectiveness and Student Learning Outcomes. The Journal of Effective Teaching, 15(1), 20-33. karakteristik bahan ajar, sifat bahan ajar dan perkembangan peserta didik sebagai langkah awalnya;

3. Hasil penelitian ini dapat dijadikan rujukan untuk menghimpun beberapa temuan penelitian khususnya dalam pendekatan eksperimen dan pendekatan expost fakto, dengan malakukan penelitian lanjutan.

Rasmita, D. (2019, Mei). Upaya Meningkatkan Kompetensi Guru dalam Pelaksanaan Proses Pembelajaran Melalui Supervisi Akademik di SD Negeri 017 Pasir Emas. Jurna PAJAR (Pendidikan dan Pengajaran), 3(3), 560 - 569.

Sagala, S. (2009). Konsep dan Makna Pembelajaran. Bandung: Alfabeta.

Sardiman. (2014). Interaksi \& Motivasi Belajar Mengajar (22 ed.). Jakarta: Rajawali Pers.

Soetjipto, \& Kosasi, R. (2007). Profesi Keguruan. Jakarta: Rineka Cipta.

Susanto, A. (2016). Teori Belajar \& Pembelajaran di Sekolah Dasar. Jakarta: Prenadamedia Grup. 